\title{
MANFAAT MINUMAN JAHE MERAH DALAM MENGURANGI DISMENOREA PRIMER
}

\author{
Ana Mariza1), Sunarsih2) \\ ${ }^{1}$ Dosen Prodi Kebidanan Universitas Malahayati \\ Email: anamariza 22@gmail.com \\ ${ }^{2}$ Dosen Prodi Kebidanan Universitas Malahayatai \\ Email: sunarsih.unmal@yahoo.com
}

\begin{abstract}
Dysmenorrhea is the most common complaint of gynecological patients. Primary dysmenorrhoea often occurs at a young age / adolescent with complaints of pain such as cramps and its location in the middle of the uterus. Dysmenorrhea affects $75 \%$ of all women. As many as $14-26 \%$ of adolescents cannot participate in activities as a result of dysmenorrhea. Dysmenorrhea can be treated through non-pharmacological therapy, one of which is using red ginger. The purpose of this study was to determine the benefits of red ginger in reducing primary dysmenorrhea in students of Bandar Lampung Muhammadiyah 2 High School.

Research type experiment, the study design used pre experimental design with the approach of one group pre test post test design. The population is 224 Muhammadiyah 2 high school students in Bandar Lampung with a total of 34 students, with a purposive sampling technique. Retrieval of data using NRS pain scale observation sheet. Data analysis using univariate and bivariate with T-Test.

The results showed the results of the T-Test that $p$-value $0,000<\alpha(0,05)$ so that it can be concluded that red ginger is useful in reducing primary dysmenorrhoea in adolescents. For teenagers, they are expected to be able to consume red ginger drinks in dealing with dysmenorrhea
\end{abstract}

Keywords: Red Ginger Drinks, Dysmenorrhoea

\section{ABSTRAK}

Dismenorea merupakan keluhan pasien ginekologi yang paling umum terjadi. Dismenorea primer sering terjadi pada usia muda/remaja dengan keluhan nyeri seperti kram dan lokasinya ditengah bawah rahim. Dismenorea dialami $75 \%$ dari seluruh wanita. Sebanyak $14-26 \%$ remaja tidak dapat mengikuti kegiatan sebagai akibat dari dismenorea. Dismenorea dapat ditangani melalui terapi non farmakologis, salah satunya menggunakan jahe merah.. Tujuan penelitian ini adalah mengetahui manfaat jahe merah dalam mengurangi dismenorhea primer pada siswi SMA Muhammadiyah 2 Bandar Lampung.

Jenispenelitianeksperimen, rancangan penelitian menggunakan pre eksperimental design dengan pendekatan one group pre testpost test design. Populasi adalah siswi SMA Muhammadiyah 2 Bandar Lampung sebanyak 224 siswi, sampel berjumlah 34 dengan teknik purposive sampling. Pengambilan data menggunakan lembar observasi skala nyeri NRS. Analisa data secara univariat dan bivariat dengan uji T-Test.

Hasil penelitian menunjukkan hasil uji T-Test bahwa p-value $0,000<a(0,05)$ sehingga dapat disimpulkan bahwa jahe merah bermanfaat dalam mengurangi dismenorea primer pada remaja. Bagi remaja diharapkan untuk dapat mengkonsumsi minuman jahe merah dalam menangani dismenorea

Kata kunci : Minuman Jahe Merah, Dismenorea

\section{PENDAHULUAN}

Kesehatan reproduksi merupakan masalah penting untuk mendapat perhatian terutama dikalangan remaja. Remaja merupakan kelompok yang memiliki berbagai kekuatan dan potensi yang hebat (Surbakti, F. B. (2009)., merekalah yang akan melahirkan generasi baru penerus bangsa (Sadli Saparinah, 2010)
Pada remaja terjadi suatu pertumbuhan fisik yang cepat disertai dengan perubahan, termasuk didalamnya pertumbuhan organ reproduksi (organ seksual) sehingga tercapai kematangan yang ditunjukan dengan kemampuan melaksanakan fungsi reproduksi. Perubahan yang terjadi pada pertumbuhan tersebut diikuti munculnya tanda seks primer. Pada perempuan kematangan organ 
reproduksi ditandani dengan datangnya menstruasi atau menarch (Widyastuti, Y., Rahmawati, A., \& Purnamaningrum, Y. E. (2009)

Menstruasi adalah proses meluruhnya jaringan endometrium karena tidak adanya telur matang yang dibuahi oleh sperma. Menstruasi merupakan hal yang wajar dan alami sehingga dapat dipastikan bahwa semua wanita normal akan memgalami proses ini. Meskipun demikian, pada kenyataannya banyak wanita yang mengalami masalah menstruasi, diantaranya adalah nyeri menstruasi (dismenorea) (Wong, M. F. (2011)

Dismenorea adalah nyeri pada waktu haid terasa diperut bagian bawah atau daerah bujur sangkar michaelis, nyeri terasa sebelum, selama dan sesudah haid. Dapat bersifat kholik atau terusterus. Dismenorea adalah nyeri perut yang berasal dari kram rahim dan terjadi selama menstruasi. Dismenorea dibagi menjadi primer dan sekunder (Pieter, H. Z., \& Lubis, N. L. (2010)

Dismenorea primer sering terjadi pada usia muda/remaja dengan keluhan nyeri seperti kram dan lokasinya ditengah bawah rahim. Dismenorea primer sering diikuti dengan keluhan mual, muntah, diare, nyeri kepala. Nyeri dismenorea yang berat menyebabkan perempuan datang berobat ke dokter atau mengobati dirinya sendiri dengan obat anti nyeri (Sarwono, H. (2014).

$\mathrm{Di}$ Indonesia presentase kejadian dismenorea primer sebesar $64,8 \%$ dan dismenorea sekunder sebesar $19,36 \%$. Pada remaja putri gejala dismenorea primer ditemukan 1 sampai 2 tahun setelah mengalami haid yang pertama. Dismenorea tersebut menyebabkan remaja tidak bisa melakukan aktivitas seperti biasanya (BKKBN.2014)

Dismenorea dapat ditangani melalui terapi non-farmakologi, salah satunya menggunakan jahe merah. Seperti teori yang menyatakan bahwa jahe merah direkomendasikan untuk wanita penderita dismenorea. Jahe merah mengandung senyawa penting diantaranya yaitu oleoresin (gingerol dan shogoal), fenol (gingerol dan zingeron). Zat gingerol didalam jahe memiliki sifat pereda rasa sakit, antipiretik dan sedatif. Penggunaanya yaitu jahe yang dikeringkan dalam bentuk kapsul (250 mg 4x/hari selama 4-5 hari). Mengunyah umbi dianjurkan sebagai obat cepat (Sinclair, C. (2010).

Jahe merah mempunyai kandungan mintak atsiri serta mempunyai rasa yang pedas karena adanya senyawa keton yang diberi nama zingeronv (Andareto, O. (2015). Kandungan minyak atsiri pada jahe merah lebih tinggi dibandingkan jahe jenis lainnya (Pramudya, Adi. 2016. Kandungan minyak atsiri jahe merah sekitar $3,9 \%$, sementara jahe emprit mengandung 1,5-3,5\% minyak atsiri, sedangkan jahe gajah hanya memiliki kandungan minyak atsiri sekitar $1,6 \%$ saja (Hariana, H. A. (2013)

\section{METODOLOGI PENELITIAN}

Jenis penelitian eksperimen, rancangan penelitian menggunakan Pre experimental design denganpendekatan one group pre dan post test pendekatan one group pre test post test. Penelitian dilakukan di SMA Muhammadiyah 2 Bandar Lampung pada tanggal 9 April - 4 Juni 2018. Populasi adalah siswi SMA Muhammadiyah 2 Bandar Lampung sebanyak 224 siswi, sampel berjumlah 34 dengan teknik purposive sampling. Pengambilan data menggunakan lembar observasi skala nyeri NRS. Analisis data menggunakan uji ttest.

\section{HASIL PENELITIAN}

Pada tabel 1, diketahui bahwa sebelum dilakukan intervensi terhadap 34 responden, mean skala nyeri menstruasi adalah 5,82. Sedangkan setelah intervensi diketahui bahwa mean skala nyeri menstruasi adalah 3,68 . Berdasarkan analisis data dengan uji T-Test menunjukkan bahwa $p$-value $0,000<a(0,05)$ sehingga dapat disimpulkan bahwa jahe merah bermanfaat dalam mengurangi dismenorea primer pada remaja.

Tabel 1 Manfaat Minuman Jahe Merah Dalam Mengurangi Dismenorea Primer

\begin{tabular}{|c|c|c|c|c|c|c|c|}
\hline Skala Nyeri Mentruasi & $\mathrm{N}$ & Mean & SD & & $95 \%$ & $\mathrm{~T}$ & Sig. (2-tailed) \\
\hline $\begin{array}{l}\text { Skala Nyeri Menstruasi Sebelum } \\
\text { Intervensi }\end{array}$ & 34 & 5.82 & \multirow{2}{*}{.958} & \multirow{2}{*}{1.813} & \multirow{2}{*}{2.481} & \multirow{2}{*}{13.073} & \multirow{2}{*}{0.000} \\
\hline $\begin{array}{l}\text { Skala Nyeri Menstruasi Sesudah } \\
\text { Intervensi }\end{array}$ & 34 & 3.68 & & & & & \\
\hline Valid N (listwise) & 34 & & & & & & \\
\hline
\end{tabular}




\section{PEMBAHASAN}

Berdasarkan hasil uji statistik diketahui terdapat penurunan skala nyeri sebelum dan setelah dilakukan intervensi yaitu sebelum dilakukan intervensi mean skala nyeri menstruasi adalah 5,82. Sedangkan setelah intervensi diketahui bahwa mean skala nyeri menstruasi adalah 3,68 dengan beda mean 2,14. Berdasarkan uji analisa data dengan uji T-test bahwa $p$-value $0,000<a(0,05)$ sehingga dapat disimpulkan bahwa jahe merah bermanfaat dalam mengurangi dismenorea primer pada remaja.

Jahe merah mempunyai kandungan mintak atsiri serta mempunyai rasa yang pedas karena adanya senyawa keton yang diberi nama zingeron (Andareto, O. (2015). Kandungan minyak atsiri pada jahe merah lebih tinggi dibandingkan jahe jenis lainnya (Pramudya, Adi. 2016) Kandungan minyak atsiri jahe merah sekitar $3,9 \%$, sementara jahe emprit mengandung 1,5-3,5\% minyak atsiri, sedangkan jahe gajah hanya memiliki kandungan minyak atsiri sekitar 1,6\% (Hariana, H. A. (2013)

Minyak atsiri memiliki kegunaan lain yaitu untuk merangsang enzim pencernaan bekerja lebih optimal sekaligus menetralkan asam penyebab mual, kram, serta diare. Jadi jahe dapat dimanfaatkan untuk mencegah atau mengatasi sakit perut dan kembung. Para pakar kesehatan bahkan menyatakan tingkat keberhasilan hingga $75 \%$ dalam penggunaan jahe sebagai pereda morning sickness dan gastroenteritis (flu perut) (Andareto, O. (2015)

Produk olahan jahe dapat berupa jahe segar, jahe kering, jahe instan, bubuk jahe, sirup jahe, selai jahe, dan jahe kristal. Secara turun menurun, kulit rimpang jahe merah yang dipanggang menjadi hitam banyak digunakan sebagai obat mencret dan disentri. Selain itu, bisa digunakan juga oleh para wanita yang ingin mengurangi nyeri menstruasinya(Lentera.T 2002). Jahe merah juga merupakan analgesik yang kuat sehingga dapat digunakan sebagai pereda nyeri (sendi atau otot) dan menghilangkan peradangan (Andareto, 0 . (2015)

Penelitian Suparmi pada tahun 2016 dengan judul Upaya Mengurangi Dismenorea Primer dengan Ekstrak Jahe Asam Jawa Pada Mahasiswi Kebidanan Stikes Aisyah Surakarta terhadap 36 responden dengan menggunakan rancangan penelitian quasi eksperimen dengan non-equivalent pretest-posttest with control group, pengambilan sampel menggunakan quota sampling. Uji statistic Wilcoxon sign rank test. Diketahui terdapat penurunan skala nyeri setelah 5 hari pemberian ekstrak jahe asam jawa (Suparmi, S. (2016)
Jahe bermanfaat mengurangi nyeri dismenorea dikarenakan kandungan yang terdapat didalam jahe membantu merangsang tubuh mengendalikan rasa nyeri didalam tubuh. Kandungan minyak atsiri yang diterima tubuh meningkatkan kemampuan tubuh seseorang menetralkan kram terutama saat menstruasi. Penelitian yang dilakukan oleh Gita Kostania pada tahun 2015 dengan judul Perbedaan Efektifitas Ekstrak Jahe dengan Ekstrak Kunyit Dalam Mengurangi Dismenorea Primer Pada Mahasiswi di Asrama Jurusan Kebidanan Poltekkes Surakarta.Tujuan penelitian adalah untuk mengetahui perbedaan efektivitas ekstrak jahe dengan ekstrak kunyit dalam mengurangi nyeri dismenorea primer pada mahasiswi di asrama Kebidanan Poltekkes Surakarta. Jenis penelitian adalah eksperiment, dengan pendekatan true experimental, menggunakan rancangan pretestposttes control group design. Kriteria sampel adalah purposive random sampling, jumlah total sampel sebanyak 60 responden dibagi menjadi tiga kelompok sama besar: kelompok perlakuan ekstrak jahe, kelompok perlakuan ekstrak kunyit, dan kelompok placebo. Masing-masing kelompok berjumlah 20 responden. Hasil: data berdistribusi normal, dengan jumlah total responden pada akhir penelitian 56 (perlakuan ekstrak jahe $=19$, ekstrak kunyit $=19$, dan placebo=18). Terdapat perbedaan efektivitas ekstrak jahe dengan ekstrak kunyit dalam mengurangi nyeri dismenorea primer pada mahasiswi di asrama Kebidanan Politeknik Kesehatan Surakarta $(p=0,04<0,05)$. Ekstrak jahe lebih efektif dalam mengurangi nyeri haid dibanding ekstrak kunyit (t-hitung $=9,690>4,802$ )

Jahe bermanfaat menurunkan nyeri dismenorea primer pada remaja meskipun tidak sampai menghilangkan nyeri. Banyak faktor yang dapat mempengaruhi intensitas nyeri sesorang. Ambang nyeri setiap orang berbeda-beda, selain itu indeks masa tubuh dan aktifitas fisik juga dapat membantu menurunkan intensitas nyeri. Oleh sebab itu selain terapis non farmakologis, setiap orang perlu memperhatikan faktor-faktor yang dapat membantu penurunan intensitas nyeri.

\section{SIMPULAN}

Minuman jahe merah bermanfaat dalam mengurangi dismenorea primer pada siswi SMA Muhammadiyah 2 Bandar Lampung dengan $P$ Value 0,000 .

\section{SARAN}

Minuman jahe merah terbukti bermanfaat dalam mengurangi dismenorea primer pada wanita, 
untuk itu disarankan bagi remaja untuk dapat mengkonsumsi minuman jahe merah karena terbukti jahe merah mengandung minyak atsiri yang memiliki kegunaan yaitu untuk merangsang enzim pencernaan bekerja lebih optimal sekaligus menetralkan asam penyebab mual, kram, serta diare. Jahe merah diolah menjadi bubuk, kemudian dicampur dengan air hangat serta ditambahkan madu. Jadi jahe dapat dimanfaatkan untuk mencegah atau mengatasi sakit perut dan kembung serta nyeri haid. Sehingga dapat mengatasi nyeri haid secara non farmakologi dengan menggunakan minuman herbal jahe merah. Pada penelitian selanjutnya diharapkan dapat meneliti manfaat lain dari jahe merah ini sendiri.

\section{DAFTAR PUSTAKA}

Andareto, O. (2015). Apotik Herbal Di Sekitar Anda. Pustaka IImu Semesta, 161-162.

BKKBN.2014.PrevalensiPenderitaDismenore di Indonesia. Dalam www. Jurnal kesehatan reproduksi.com

Hariana, H. A. (2013). 262 tumbuhan obat dan khasiatnya. PenebarSwadayaGrup

Lentera, T. (2002). Khasiat dan manfaat jahe merah si rimpang ajaib. AgroMedia.
Pramudya, Adi. 2016. Budi Daya dan Bisnis Jahe. Jakarta: Agromedia Pustaka

Pieter, H. Z., \& Lubis, N. L. (2010). Pengantar psikologi untuk kebidanan. Jakarta: Kencana Prenada Media Group.

Sadli Saparinah, 2010. Berbeda tapi Setara, Pemikiran Tentang Kajian Perempuan. Jakarta: Penerbit Buku Kompas

Sarwono, H. (2014). Kematian Maternal. IImu Kandungan Sarwono Prawirohardjo, 7.

Sinclair, C. (2010). Buku saku kebidanan. Jakarta: EGC

Suparmi, S. (2016). Upaya Mengurangi Dismenore Primer Dengan Ekstrak Jahe Asam Jawa Pada Mahasiswi Kebidanan Stikes Aisyiyah Surakarta.Gaster| JurnalllmuKesehatan, 14(2), 78-89.

Surbakti, F. B. (2009). Kenalilah anak remaja anda. Elex Media Komputindo.

Widyastuti, Y., Rahmawati, A., \& Purnamaningrum, Y. E. (2009). Kesehatanreproduksi. Yogyakarta: Fitramaya, 26(66), 2.

Wong, M. F. (2011). PanduanLengkapPijat. Penebar PLUS+. 